\title{
Transforming communicative spaces: the rhythm of gender in meetings in rural Solomon Islands
}

\author{
Michelle Dver ${ }^{1,2}$
}

\begin{abstract}
Women's lack of participation in important decision making is noted as an obstacle to sustainable development in many parts of the world. An initial issue for gender equity in environmental decision making in many developing country contexts is not only women's inclusion but also their substantive participation in decision-making forums. In this article I examine the power structures embedded in the public communicative spaces in a village in the Western Province of Solomon Islands using empirical data in conjunction with ethnographic understanding of gendered meeting styles. The data reveal some reasons why women may be silenced as public political actors. It also raises the potential for development actors to create conceptual space for specific women's ways of meeting and validating women's meeting styles. These findings have implications for encouraging transformative communicative spaces and formats that allow transcendence of socially embedded power structures.
\end{abstract}

Key Words: development; gender; meetings; Solomon Islands; transformative communicative practice; women's empowerment

\section{INTRODUCTION}

In this article I explore the gendered social space of community meetings in rural Solomon Islands. I aim to understand how external agents may create new communicative spaces that transform gendered power dynamics in public speech events. A novel method of analysis is introduced to provide a tool for other researchers and development practitioners to apply in different cultural contexts. The results point to a need for greater attention to the "micro" level of gender relations at the household and community level as integral to understanding women's participation, or lack of, in important decision making and formal political positions of power at all levels (see also Meleisea et al. 2015, Evans et al. 2017). Additionally, I argue that to understand women's empowerment we need a broad view of what is political, concerned with not only "exercising power but also with reproducing the mechanisms that make that power possible" (Myers and Brenneis 1984:4 [emphasis in original]).

This research was prompted by my repeated experience with village women in Solomon Islands remaining silent at mixed gender meetings, in which they were always the majority of attendees, while engaging in robust discussion and debate in allwomen meeting settings. The research reveals how forms of meeting practice may embed the disjuncture between gender parity (i.e., equal numbers of men and women) and gender equality (i.e., equal influence), by showing how some styles of meeting, which are explicitly gendered, are considered more valid than others. Thus, it relates to transformation of communicative practices suggesting that transformative pathways may lie in validating alternate communication formats that are gendered and culturally specific. The original methodology used provides a model for analysis of gender differences in public contexts, which is discussed in the conclusion.

This research takes place in the context of international development measures for women's empowerment centered on women's public political participation at all levels. Gender parity is the most common indicator used to measure gender equality in decision making forums, from national parliaments to village councils (World Bank 2011, UN 2016, UN Women 2016).
Sustainable Development Goal 5 is: "Achieve gender equality and empower all women and girls" (UN 2016). Target 5.5 is: "Ensure women's full and effective participation and equal opportunities for leadership at all levels of decision-making in political, economic and public life" (UN 2016:24). Indicators for measuring progress to this target are the following: "5.5.1: Proportion of seats held by women in national parliaments and local governments" (UN 2016:24); and "5.5.2: Proportion of women in managerial positions" (UN 2016:29). By including women in managerial positions as an indicator the United Nations (UN) claim that these two targets present a broader picture than used to capture gender equality and women's empowerment under the Millennium Development Goals. They state: "Women's capacity to influence decision making, whether in public or private institutions, is intimately linked with gender equality and empowerment. Having a voice and participating in the processes and decisions that determine their lives is an essential aspect of women's freedoms" (United Nations 2016:30).

Although this statement by the UN recognizes the importance of gendered power in relation to "voice," the indicators used to measure women's empowerment still fail to capture this aspect. The basic problem with this indicator, across scales, is that gender parity does not equal gender equality. Additionally, gender parity in national parliaments is not consistently linked to either a country's state of development as measured by the UN's Human Development Index, or gender equality and women's empowerment as measured more broadly. For example, Rwanda is the only country worldwide to have more than $60 \%$ women in its national parliament and one of only two countries worldwide to have more than 50\% (IPU 2015). However, Rwanda rates 159 out of 188 countries on the 2016 UN Human Development Index, placing it in the very low human development category (UNDP 2015). It also scores low on the UN Gender Inequality Index (GII) at 84 , even though percentage of seats held by women in national parliament is one of the five indicators used to calculate the GII (UNDP 2015). Thus, measuring proportion of women in parliament and in managerial positions in business does not necessarily reflect broader gendered social power dynamics or their reproduction (Kabeer 2005, Cornwall and Rivas 2015). 
The question is, what else is needed aside from gender parity to achieve gender equality? The knowledge gap in this area of research is in understanding, first, the reasons for the disjuncture between gender parity and gender equality and second, underlying structures that support and reproduce communicative practices that silence women and how they may be transformed.

Empirical studies have found that even when women are present at meetings they are still consistently less likely than men to substantively participate. Agarwal (2010:108) claims that women are more likely to speak up at a meeting when they constitute a third or more of meeting attendees, what she calls the "critical mass." In an Indian context, Agarwal (1997) found that factors that inhibited women's contribution to mixed gender meetings included women's lack of public speaking experience and their feelings of apathy around contributing because of their opinions being disregarded. Kameswari (2002) claims that women's absence and silence at Joint Forest Management committee meetings in India relate partly to women's limited capacities to contribute to these meetings due to their inexperience or illiteracy. Agarwal and Kameswari conclude that there is no direct relationship between gender parity at meetings and gender equality.

Rather, Agarwal (2010) claims that women will speak up when they have a "personal stake" in the issue. She defines "personal stake" as certain topics related directly to the gendered division of labor and seen as women's areas of concern; what we may call "women's business." What is considered "men's business" and "women's business" differs across cultures but similarities are apparent globally in the domination of business and politics by men and the relegation of unpaid work and family care labor to women. However, I question the conflation of "personal stake" with "women's business." Women's business is culturally defined and is conceptually different from issues that substantially affect women's lives. That is, to construe topics considered as women's work as women's personal stake underemphasizes the factors that sanction what is considered women's appropriate contributions. Although women may have a personal stake in certain topics at meetings, such as land issues, they may not speak up because of cultural constructions of when and on what topics it is considered appropriate and respectful for women to speak publicly (Macintyre 2003).

Gendered norms around public speech contribute to an absence of women in strategic decision making. Meetings, across many cultural contexts, are a form "primary communicative practice" that display and manipulate rights to information and influence (Tracy and Dimock 2004). As Gal (1991:177) points out,

...respected linguistic practices are not simply forms, they deliver characteristic cultural definitions of social life, that embodied in divisions of labour and the structure of institutions, serve the interests of some groups better than others. Indeed, it is in part through such linguistic practices that speakers within institutions impose on others their group's definition of events, people and actions. This ability to make others accept and enact one's representation of the world is another aspect of symbolic domination.
In this article, these issues are explored by interrogating the gendered nature of communicative space that enables or constrains women's engagement in community meeting settings in rural Solomon Islands.

\section{Context}

Solomon Islands is a chain of islands in the Pacific Ocean, spread across $2000 \mathrm{~km}$ of sea between Bougainville and Vanuatu (Fig. 1). There are nine main island groups and nearly 1000 small islands and atolls comprising a land mass of $28,400 \mathrm{~km}^{2}$. Solomon Islands rates poorly on the United Nations Human Development Index, 156 out of 187 countries in 2015 (UNDP 2015). It has the lowest gross national income per capita in the Pacific (UNICEF 2011:12) and ranked second worldwide between 2009 and 2011 of Aid-to-Gross National Income ratios of the top 20 aid dependent nations (Pryke 2013).

Most Solomon Islanders live in rural areas on customary owned land. Customary land tenure rights are protected in the constitution and decisions around land use and natural resource management fall under the jurisdiction of customary land holding groups defined by genealogical connections, reckoned either matrilineally or patrilineally in different parts of Solomon Islands (Crocombe 1974, Maetala 2008). Forest ecosystems are integral to productive subsistence livelihoods, which, along with fishing, provide food security for the vast majority of the population. In the past, clearing of forests were mainly to establish food gardens, using swidden agricultural practices.

Economic growth is focused on natural resource extraction. Large scale logging by foreign companies on customary owned land began in the early 1980s and has been the country's largest export earner since (World Bank 2015). Mining has been predicted to take over as main export income when supply of timber from natural forests comes to an end. At the time of writing, however, logging continues and mining is not firmly established (Porter and Allen 2015). This logging regime has been marked by environmental destruction, political malfeasance, a failure of the state to regulate or control the logging industry, and unethical practices by foreign logging companies, including financial trickery (Barlow and Winduo 1997, Frazer 1997, Bennett 2000, Hviding and Bayliss-Smith 2000, Kabutaulaka 2000, 2006, Oranje and Duff 2006, Wairiu 2007, Gay 2009). It has also altered the gender of decision making around land. Logging has been considered men's business. Although theoretically gender is irrelevant to land rights under Solomon Islands customary land tenure, the domination of logging and other commercial negotiations by men has disenfranchised women in land issues (Foale and Macintyre 2000, Monson 2011, McDougall 2014, Dyer 2017a).

In Solomon Islands women are poorly represented in politics at national, provincial, and local levels. They are a small minority in leadership positions in business and within government ministries and organizations (Quay 2012). Although not discussed further in this article, violence against women is one aspect of women's disempowerment that cannot be separated from women's lack of public leadership and representation (Strachan et al. 2010, Jolly 2012, Macintyre 2012, Dyer 2017b). Countrywide studies in Solomon Islands revealed that $64 \%$ of women between the ages of 15 and 49 had experienced physical 
Fig. 1. Solomon Islands showing current provincial boundaries. (Australian National University College of Asia and the Pacific 2016).

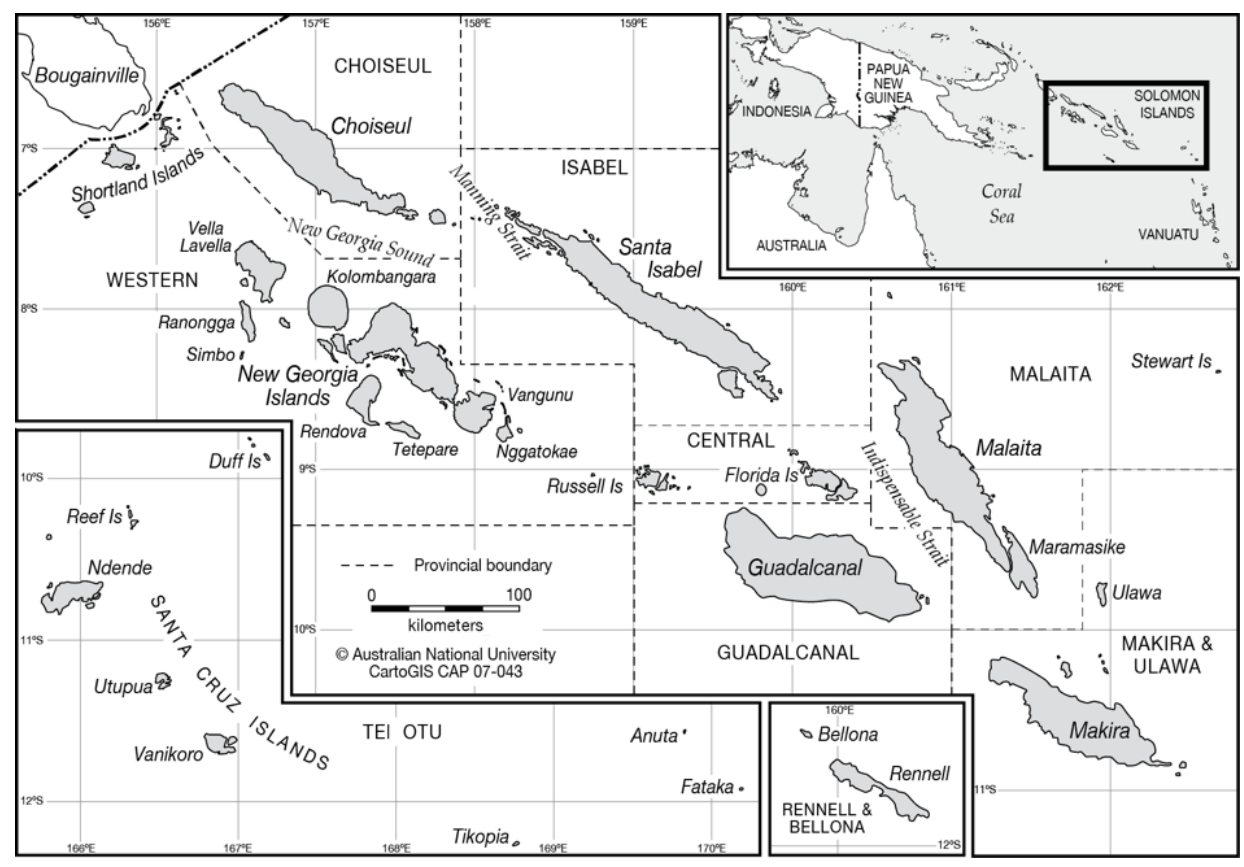

and/or sexual violence in the 12 months prior to the study (SPC 2009, as cited in Department of Foreign Affairs and Trade 2014). Being silenced or shutting up generally because of cultural notions of respect in specific social spaces, for fear of social sanction, or the threat of violence, represents a barrier to women's freedoms and empowerment on many fronts, including leadership, decision making, and intrahousehold conflict and negotiation.

Based on other work on meetings in Melanesia, I start with the premise that all types of meetings reflect the distribution of authority and reinforce or challenge it (Brison 1992). However, in the Melanesian cultural context it does not necessarily follow that important decisions are made at the public meeting (Lederman 1980, White and Watson-Gegeo 1990, Brison 1992, Monson 2012). Rather, the function of meetings as formal speech events may be more related to public re-enactment and reinforcement of political and social hierarchy. Who may speak, how, and when they speak, are deliberate acts informed by cultural context.

In Solomon Islands, and much of the Pacific, formal public meetings are often a means by which already established positions are presented and subtle political manoeuvring may take place (Lederman 1980). Women are most often excluded from these informal manoeuvres, and hence also from full participation in the public performances that cement them. Meetings then, rather than opportunities for discussion and decision making, are often a stage for the enactment of drama for certain purposes (Lederman 1980, Myers 1986, Brison 1992, McDougall 2005). In these cases, the formal mechanisms of the community meeting exist in the space created by the tension between assertions of individual rights and power brokering, and maintenance of social cohesion and collective identity. This is true in many cases whether the meeting is internal to the community or involves outside development organizations or corporate interests (for some examples in the Pacific see Myers 1986, Brison 1992, Filer 1997, 2000, Hviding and Bayliss-Smith 2000, Foale 2001, Macintyre and Foale 2004, Kabutaulaka 2006).

Additionally, people's influence at the meeting is derived from a number of established factors related to social positioning that gives them social power. For example, the most influential man at the meeting may say nothing until the end of the meeting and yet his opinion may hold sway. Silence, in all men meetings is not necessarily a sign of powerlessness on behalf of men who do not make lengthy contributions. Rather, "linguistic forms...are strategic actions, created as responses to cultural and institutional contexts" (Gal 1991:176). Thus, women's silence in mixed gender meetings may be seen as adherence to cultural norms about appropriate behavior for certain types of meetings and specifically for women in this meeting context.

I make three main points in this article. First, gender parity does not equal gender equality at meetings because of cultural constructions of influence and gendered behavior and also contrary to other research about a "critical mass" of women's attendance at meetings in order to enable their participation. Second, men's and women's meetings have fundamentally different rhythms. Finally, options for disrupting gender hierarchical communication processes in research, development, and other projects at a structural level are present in validating and recognizing alternate communicative practices. The overall goal of the article is to encourage a revaluing of women's denigrated linguistic and social practices (Gal 1991) and invite further reflection on creating spaces for disruption of other power dynamics. 


\section{METHODS}

I present two sets of data on meetings in Solomon Islands villages. The first details gendered attendance and contribution to 18 community meetings in one village to distinguish between attendance and contribution at meetings (parity versus equality). The second set of data uses a novel quantitative method to graphically present gendered rhythms of four comparable meetings.

This paper makes a contribution to formulating more gender sensitive development practice from an anthropological ethnographic perspective. The author attended meetings analyzed only as observer. At all meetings in the dataset the author was the only non-Solomon Islander national and was not part of setting meeting agenda, organization, format, or any other directional or administrative details. This is a viewpoint not often available to development or conservation practitioners who may only be in the village briefly and to run their development meeting, program, workshop, or other kind of initiative. Thus, the data presented here represents modern Solomon Islander practice. I make no claim that it is therefore somehow "traditional" or indicative of reversion to culturally "unpolluted" epistemology, but rather that it represents "business as usual" for these Solomon Islander villages.

The quantitative data presented in this paper are drawn from attendance at village meetings during seven months' continuous residence in the Western Province in 2014 (Fig. 2). I also attended many other meetings and all-women meetings, as observer, participant, or facilitator, in villages in Western, Malaita, and Choiseul provinces between 2012 and 2015. I attended these meetings in the capacity of a research assistant for academic research, a $\mathrm{PhD}$ researcher, and as a development practitioner for two different nongovernmental organizations. Qualitative observations and insights here are drawn from these experiences and complement the quantitative data.

Fig. 2. New Georgia Island group, Western Province. (Australian National University College of Asia and the Pacific 2016).

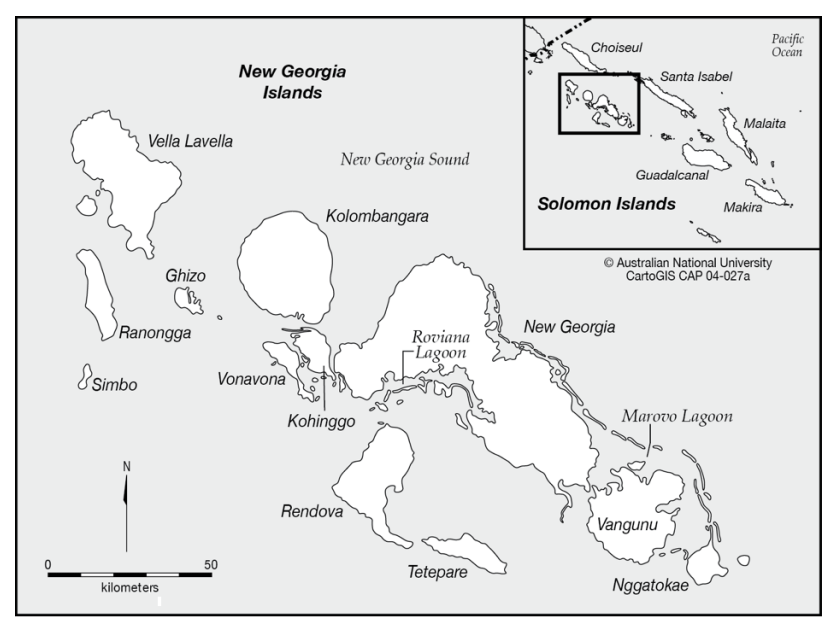

The research undertaken as part of doctoral fieldwork was funded by an Australian Post-Graduate Award and James Cook University College of Arts, Education and Society. Ethics approval was granted by James Cook University and a research permit was granted by the Solomon Islands Government. All interviews, discussions, and recordings took place with prior written and verbal consent from participants.

The first dataset, Figs. 3 and 4, was generated at 18 village level community meetings in one village in the Western Province of Solomon Islands. Each meeting in the dataset has the following characteristics:

Fig. 3. Women's attendance and contribution to meetings.

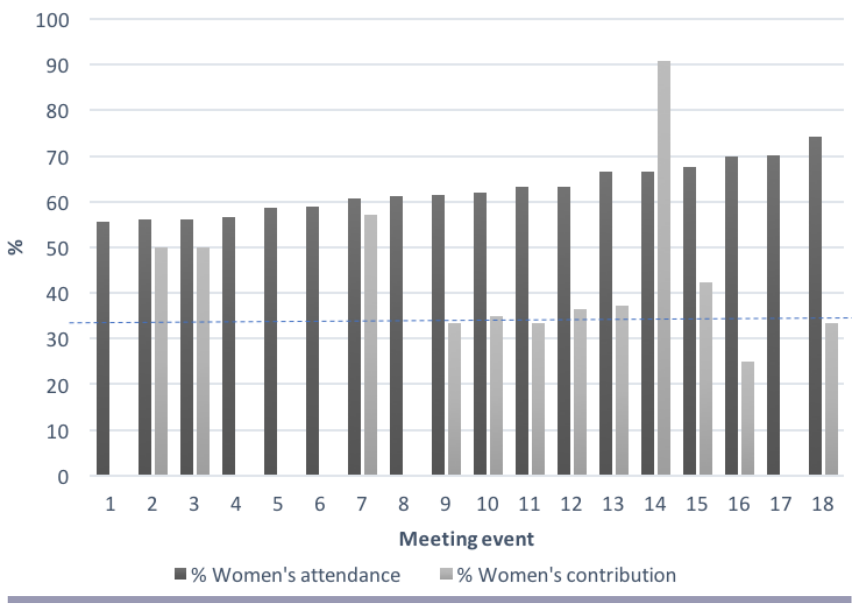

Fig. 4. Men's attendance and contribution to meetings.

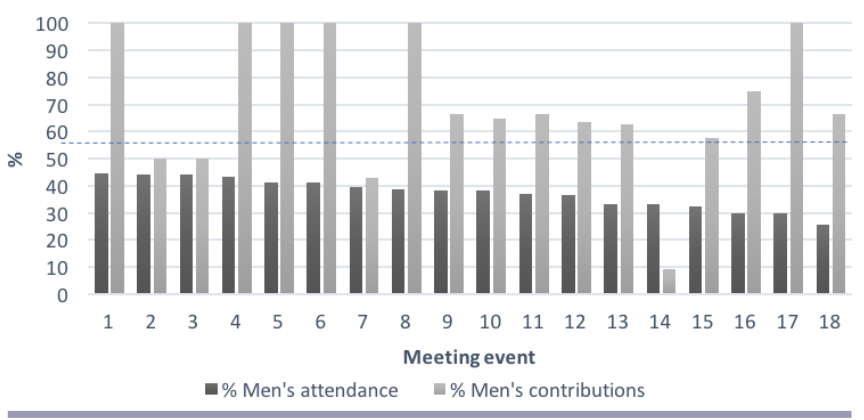

- open to all community members;

- called by the village chairman;

- announced by blowing the conch shell;

- held in the village meeting house;

- had an agenda and a chair;

- attended by both men and women;

- topic concerned the village community generally; and

- internal to the village (no outside organizations were involved). 
Indicators of attendance and contribution were used to differentiate degrees of participation. Attendance was defined as people present at the meeting for $80 \%$ or more of the total meeting time. This definition of attendance aligns to "passive participation" typology: attending meetings, listening, not speaking up, as distinct from contribution (Agarwal 2010). Contribution was defined by spoken input to the meeting. Frequency of contribution was counted by separate input at different times. This definition of contribution may be classified as "active participation," "expressing opinions, whether or not solicited, or taking initiatives of other sorts"(Agarwal 2010:101).

The second dataset (Figs. 5 to 11) used audio recordings of four meetings. These four meetings were not part of the first dataset. The four meetings shared three characteristics:

1. Dominated by one gender or one gender only present: two meetings men dominated, two meetings women dominated.

2. Origin of meeting: two meetings internal to the community, two meetings called by nongovernmental organizations.

3. Purpose of meeting: two meetings for information sharing, two meetings for dispute resolution.

From each meeting recording a Gantt chart was constructed (Figs. 5 to 9). The first column of the chart shows individual speakers and the first row shows speaking time noted at 30 second intervals for 30 minutes of total meeting time. The two final rows of each chart show "whispering/side murmurings" and "laughter." "Whispering/side murmurings" were defined as speaking between attendees that was not addressed to the meeting at large but still about the meeting topic. "Laughter" was defined as general laughter in the meeting.

The meeting-Gantt charts show (1) how many people contributed during the recorded 30-minute interval; (2) role of the chair in the meeting; (3) frequency of individual speaker contributions; (4) length of individual speaker contributions; (5) overlapping speaker contributions; and (6) general volume level of the meeting overall

\section{RESULTS}

Gendered contribution versus attendance

There was no correlation between proportional attendance of women or men at meetings and contributions (Figs. 3 and 4). Men always contributed more than women regardless of how many men or women were at the meeting except when the meeting topic was about issues clearly defined as women's business. Meetings that show women's contributions at over $40 \%$ were about organizing communal feeding and cooking efforts for various events and at the Parent and Teacher Association (PTA) meeting for the village primary school. The outlier of $91 \%$ women's contribution (event 14) was a meeting with three agenda items that required the women to undertake large amounts of cooking for each task: a funeral feast, a school fundraising event, and feeding workers at the regional health clinic infrastructure upgrade. Women were exclusively responsible for the cooking at these three events, and much discussion took place between the women to coordinate who was doing what and when.

\section{Gendered meeting rhythm}

In women-only or women-dominated meetings women contributed for shorter periods of time and more frequently than men regardless of the type of meeting: information sharing or dispute resolution (Figs. 8 and 9). The busy visual picture of Figures 6 and 9 represent the louder and looser style of women's meetings compared to men's. Women often spoke rapidly one after another, sometimes at the same time and engaged in side discussions while other speakers were addressing the meeting. Laughter and whisperings/side murmurings were a distinct feature of women-only or women-dominated meetings that was almost entirely absent in men's meetings. In men's meetings speakers took turns to speak moderated by the chair and usually contributed only once to the meeting overall, shown in Figures 5, 7 , and 8 .

\section{DISCUSSION}

\section{The social validity of gendered meeting styles}

Although there was no correlation between proportion of men's and women's attendance and their contributions in the 18 community meetings in the first dataset, women's contributions in these meetings correlated strongly to topics about food and children. It was only when the meeting related to these topics that they contributed more than $50 \%$ of the meeting even though at all meetings they constituted more than $50 \%$ of attendees. The second dataset and Gantt charts demonstrate divergent gendered meeting styles. Taken in combination the two datasets show that women have opinions and are willing and able to express them but that, as shown in the community mixed gender meetings data, they are constrained to contributing in specific contexts that are embedded with powerful norms that dictate what and how they contribute. Kameswari (2002:797) terms this, "norms of acceptable behaviour [and] notions[s] about appropriate spaces."

Thus, while it is worth aiming for gender parity at meetings it can be misleading to focus purely on numbers of men and women present. The texture of the meeting, presented in Figure 6 follows women's meeting practice in contrast to men's, even though men were present. This can be seen again in Figure 9. The salient point here is that when the meeting space was clearly established as a women's meeting space, the meeting practice followed a significantly different pattern than men's and mixed gender community meetings. In the women's meeting space women took up the space of the meeting, even though there were men present.

It is interesting then to compare Figure 6, women's information sharing meeting at which there were men present and Figure 9, women's dispute resolution meeting at which there were no men present. Women's meeting practice in Figure 9 exhibits an even stronger contrast when no men are present to mixed gender and all-men meetings. Figure 9 stands as an apogee of women's meeting practice. By contrast there is very little difference between men's meeting practice whether women were present (Meeting 3, Figs. 5 and 6) or not (Meeting 1, Fig. 4).

The presentation of data in these graphs is purely a numbers game and must be read in conjunction with cultural contexts. It does not tell us about the weight of influence of various speaker's contributions regardless of how long they speak for or how many times they contribute. Additionally, it does not differentiate along other axes of social differentiation within gendered groupings, for 
Fig. 5. Meeting 1: Men's information sharing meeting with nongovernmental organization. No women present.

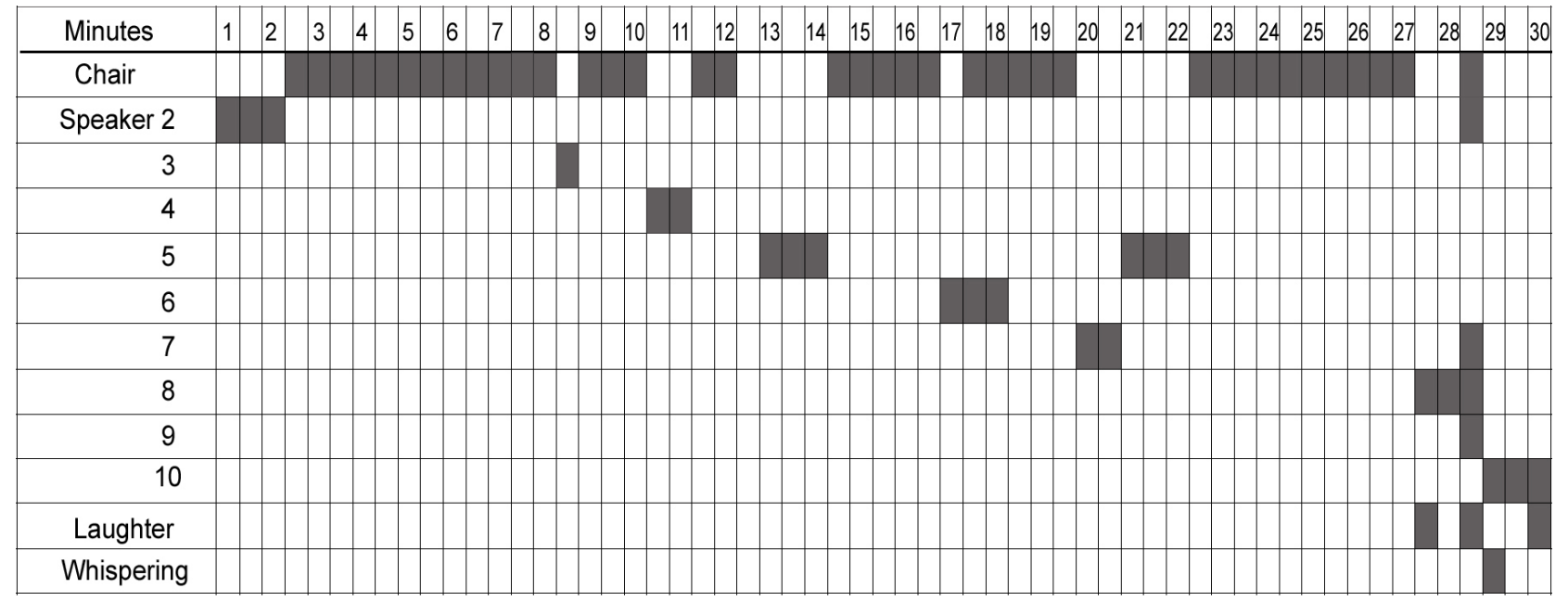

Fig. 6. Meeting 2: Women's information sharing meeting with nongovernmental organization. Men present but did not make any contributions.

\begin{tabular}{|c|c|c|c|c|c|c|c|c|c|c|c|c|c|c|c|c|c|c|c|c|c|c|c|c|c|c|c|c|c|}
\hline Minutes & 1 & 2 & 3 & 4 & 5 & 6 & 7 & 8 & 9 & 10 & 11 & 12 & 13 & 14 & 15 & 16 & 17 & 18 & 19 & 20 & 21 & 22 & 23 & 24 & 25 & 26 & 27 & 28 & 2930 \\
\hline Chair & & & & & & & & & & & & & & & & & & & & & & & & & & & & & \\
\hline Speaker 2 & & & & & & & & & & & & & & & & & & & & & & & & & & & & & \\
\hline 3 & & & & & & & & & & & & & & & & & & & & & & & & & & & & & \\
\hline 4 & & & & & & & & & & & & & & & & & & & & & & & & & & & & & \\
\hline 5 & & & & & & & & & & & & & & & & & & & & & & & & & & & & & \\
\hline 6 & & & & & & & & & & & & & & & & & & & & & & & & & & & & & \\
\hline 7 & & & & & & & & & & & & & & & & & & & & & & & & & & & & & \\
\hline 8 & & & & & & & & & & & & & & & & & & & & & & & & & & & & & \\
\hline 9 & & & & & & & & & & & & & & & & & & & & & & & & & & & & & \\
\hline 10 & & & & & & & & & & & & & & & & & & & & & & & & & & & & & \\
\hline Laughter & & & & & & & & & & & & & & & & & & & & & & & & & & & & & \\
\hline Whispering & & & & & & & & & & & & & & & & & & & & & & & & & & & & & \\
\hline
\end{tabular}

Fig. 7. Meeting 3: Men's community dispute resolution meeting. Women present but did not make any contributions.

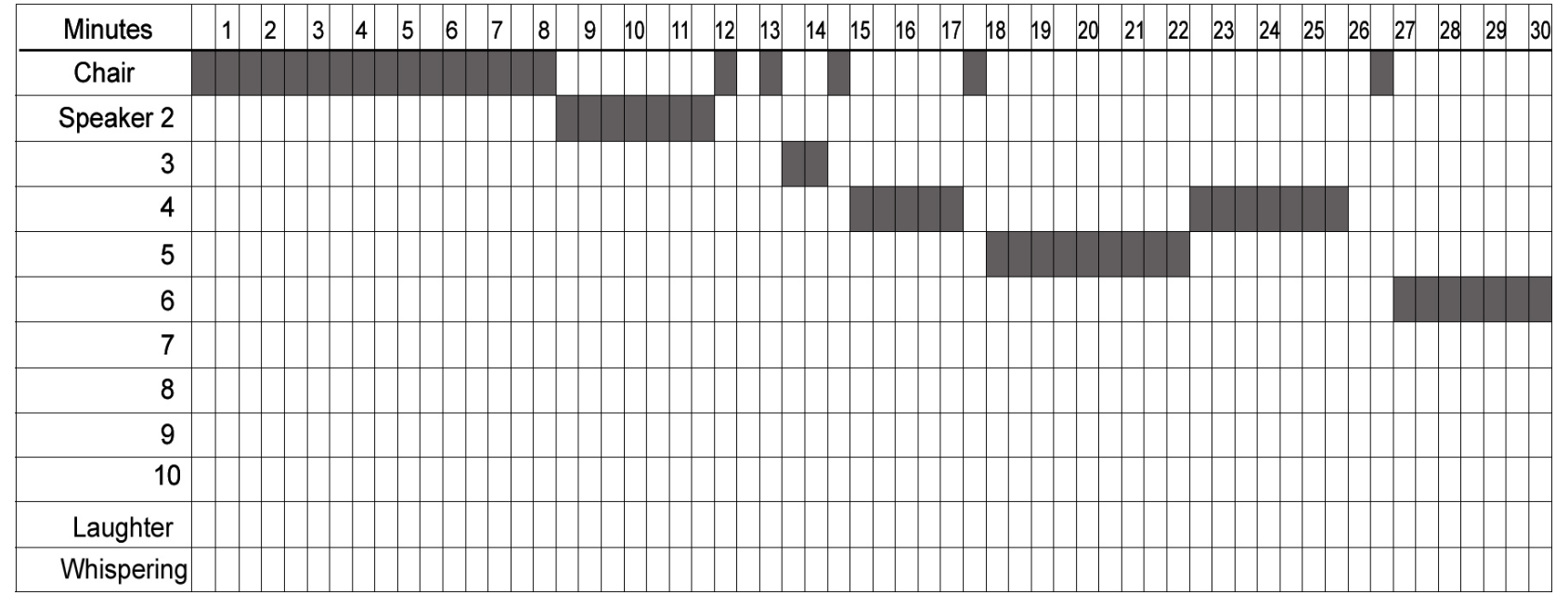


Fig. 8. Second 30 minutes of meeting 3: Men's dispute resolution meeting.

\begin{tabular}{|c|c|c|c|c|c|c|c|c|c|c|c|c|c|c|c|c|c|c|c|c|c|c|c|c|c|c|c|c|c|c|c|}
\hline Minutes & 31 & 32 & 33 & 34 & 35 & 36 & 37 & 38 & 39 & 40 & 41 & 142 & 43 & 44 & 45 & 46 & 47 & 48 & 49 & 50 & & 51 & 52 & 53 & 54 & 55 & 56 & 57 & 58 & 59 & 60 \\
\hline Chair & & & & & & & & & & & & & & & & & & & & & & & & & & & & & & & \\
\hline Speaker 2 & & & & & & & & & & & & & & & & & & & & & & & & & & & & & & & \\
\hline 3 & & & & & & & & & & & & & & & & & & & & & & & & & & & & & & & \\
\hline 4 & & & & & & & & & & & & & & & & & & & & & & & & & & & & & & & \\
\hline 5 & & & & & & & & & & & & & & & & & & & & & & & & & & & & & & & \\
\hline 6 & & & & & & & & & & & & & & & & & & & & & & & & & & & & & & & \\
\hline 7 & & & & & & & & & & & & & & & & & & & & & & & & & & & & & & & \\
\hline 8 & & & & & & & & & & & & & & & & & & & & & & & & & & & & & & & \\
\hline 9 & & & & & & & & & & & & & & & & & & & & & & & & & & & & & & & \\
\hline 10 & & & & & & & & & & & & & & & & & & & & & & & & & & & & & & & \\
\hline Laughter & & & & & & & & & & & & & & & & & & & & & & & & & & & & & & & \\
\hline Whispering & & & & & & & & & & & & & & & & & & & & & & & & & & & & & & & \\
\hline
\end{tabular}

Fig. 9. Meeting 4: Women's community dispute resolution meeting. No men present.

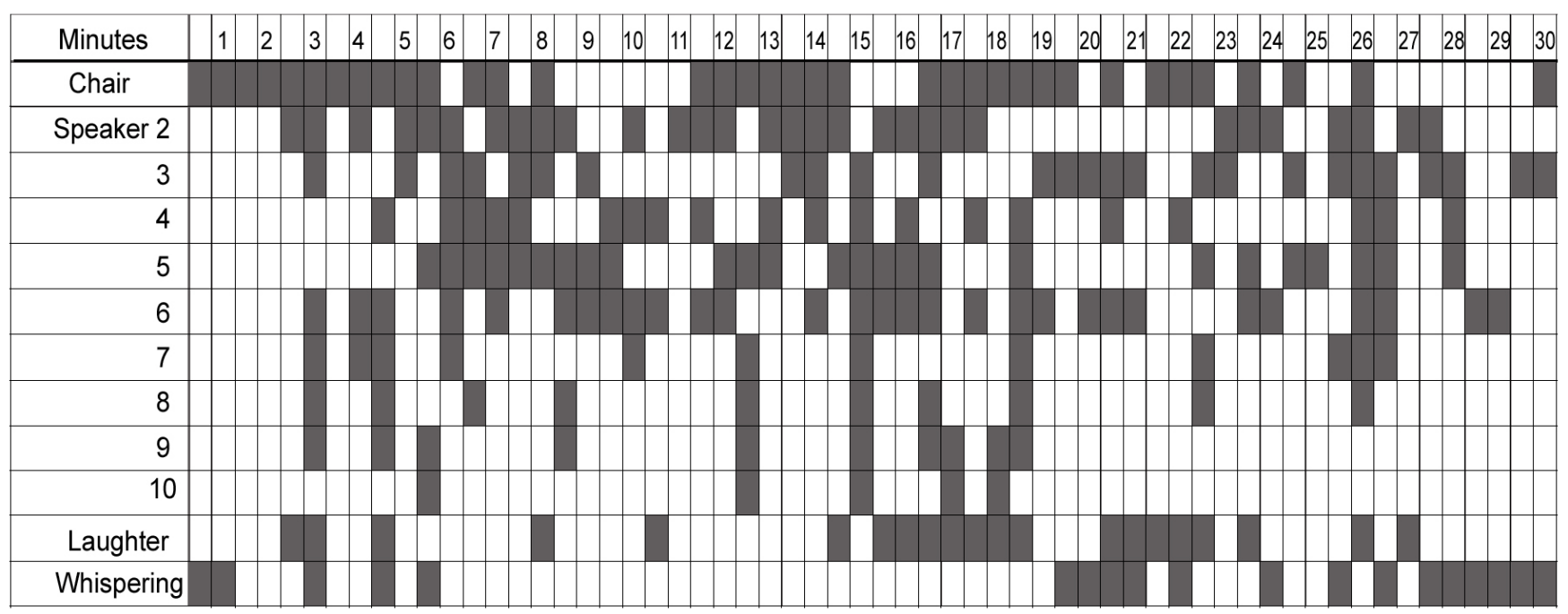

Fig. 10. Gendered styles of participation from meetings 3 and 4 , men's and women's dispute resolution meetings.

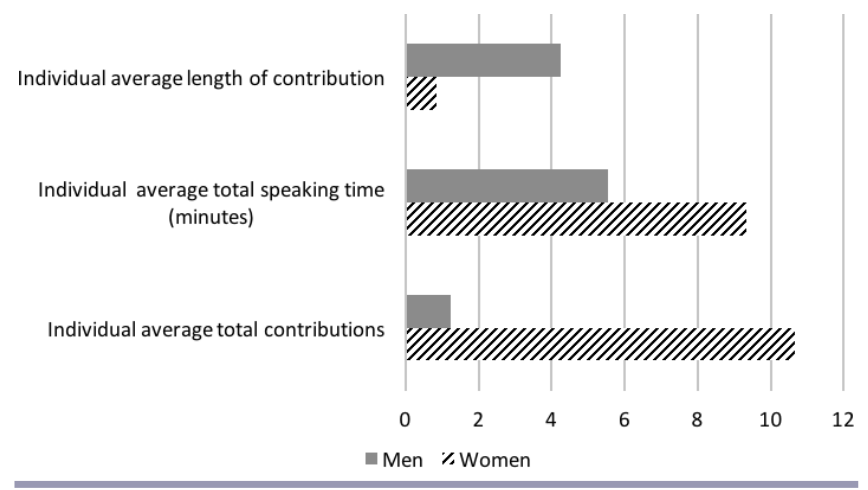

Fig. 11. Gendered styles of participation from meetings 1 and 2, men's and women's information sharing meetings.

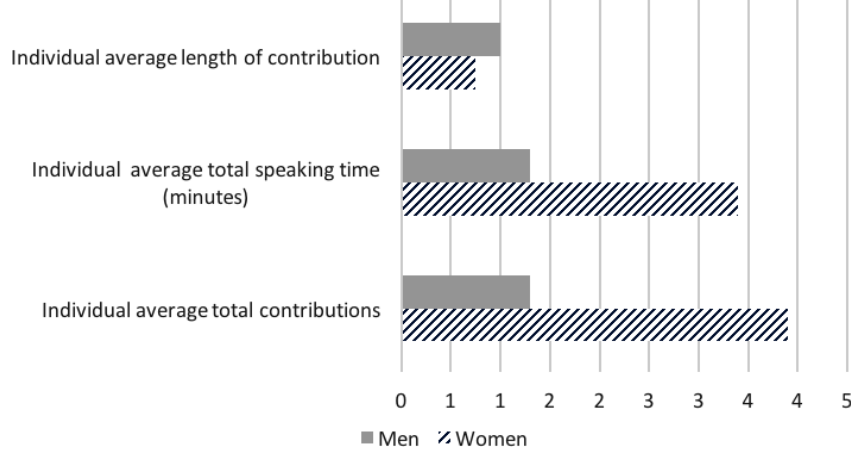


example, age, land affiliations, lineage, kin or tribal affiliations, religious affiliation and standing, or socioeconomic status. All or any of these may be relevant to the relative weight of a speaker's contributions in various contexts. This method of analysis and presentation primarily has value as a clear visual tool to show broad patterns in gendered meeting rhythm and style in a given cultural context.

\section{CONCLUSION}

These data show that practitioners in development, conservation, and other areas that facilitate meetings for whatever purposes, can create new communicative spaces to encourage women's robust contribution to discussions. Otherwise the mode of operation of meetings of external organizations may unwittingly perpetuate women's exclusion from positions of political power and participation in decision making. If external organizations run meetings only along lines that follow men's meeting styles they reinforce the notion that men's meetings styles are the legitimate form of practice for business and politics. Thus, while women-only meetings may therefore by a first important tool for enhancing women's contributions to discussions, explicit recognition of women-specific speech practices makes space for a "reshaping of political practice more generally" (Sharp et al. 2015:10), acknowledging "participation as an inherently political process rather than a technique" (Cornwall 2008:281). This perspective can challenge unequal power dynamics at a deeper, structural level rather than only strategizing about how to enable women to penetrate existing androcentric power structures. It also addresses the power dynamics of gender relations instead of focusing only on gender disaggregating tactics.

Such a technique uses what Sprain and Boromisza-Habashi (2012:180) call "a cultural approach grounded in the ethnography of communication" to deliberately embody an alternate model of the social world (Gal 1991). These insights are important in Solomon Islands and other development contexts where meetings are the primary, and sometimes only, point of contact at the interface of village communities and the development, conservation, and corporate worlds.

There are two ways external agents can use the methodology presented in this article: first, to determine the gender of participation in meetings beyond proportional representation of men and women; and second, to understand culturally and gender specific communicative practices if applied to single gender meetings. This in turn may expose gendered dominance of particular meeting styles. The gendered rhythm of meetings visible in this Solomon Islands context may differ in other cultural contexts and will be revealed by applying the analytical method used in the Gantt charts. From this one can strategize about how to allow space for transformative meeting practices that attempt to transform social power dynamics embedded in certain meeting formats.

Finally, awareness and sensitivity to how unequal gendered power dynamics in the structure of communicative practice are perpetuated can challenge discourses of women's empowerment and development that prescribe a largely instrumental role for women without recognizing their structural location (Cornwall 2003, 2008). Such insights can be applied self-reflexively to dislodge notions that developing world cultural norms are to blame for underdevelopment and gender inequality.
Responses to this article can be read online at: http://www.ecologyandsociety.org/issues/responses. php/9866

\section{Acknowledgments:}

The author wishes to acknowledge the people of Solomon Islands who participated in her research. This research was made possible by James Cook University funding (2013) and an Australian Postgraduate Award (2011-2016). Article publication and manuscript preparation was funded by the Stockholm Resilience Centre, Stockholm University. The author acknowledges and thanks Janelle Veitch, Dr Simon Foale, and Dr Andrea Downing for critical feedback and assistance in the preparation of this paper. All errors remain the author's own.

\section{LITERATURE CITED}

Agarwal, B. 1997. Environmental action, gender equity and women's participation. Development and Change 28:1-44. http:// dx.doi.org/10.1111/1467-7660.00033

Agarwal, B. 2010. Does women's proportional strength affect their participation? Governing local forests in South Asia. World Development 38:98-112. http://dx.doi.org/10.1016/j.worlddev.2009.04.001

Barlow, K., and S. Winduo. 1997. Introduction. Special Issue: Logging the Southwestern Pacific: perspectives from Papua New Guinea, Solomon Islands and Vanuatu. Contemporary Pacific 9:1-24.

Bennett, J. A. 2000. Pacific forest: a history of resource control and contest in Solomon Islands, c. 1800-1997. White Horse Press, Cambridge, UK.

Brison, K. 1992. Just talk: gossip, meetings, and power in a Papua New Guinea village. University of California Press, Berkeley, California, USA. http://dx.doi.org/10.1525/california/9780520077003.001.0001

Cornwall, A. 2003. Whose voices? Whose choices? Reflections on gender and participatory development. World Development 31:1325-1342. http://dx.doi.org/10.1016/S0305-750X(03)00086$\underline{X}$

Cornwall, A. 2008. Unpacking 'participation': models, meanings and practices. Community Development Journal 43:269-283. http://dx.doi.org/10.1093/cdj/bsn010

Cornwall, A., and A.-M. Rivas. 2015. From "gender equality" and "women's empowerment" to global justice: reclaiming a transformative agenda for gender and development. Third World Quarterly 36:396-415. http://dx.doi.org/10.1080/01436597.2015.1013341

Crocombe, R. 1974. An approach to the analysis of land tenure systems. Pages 1-17 in H. Lundsgaarde, editor. Land tenure in Oceania. The University of Hawaii Press, Honolulu, Hawaii, USA.

Department of Foreign Affairs and Trade. 2014. Pacific women shaping Pacific development: Solomon Islands country plan summary. Australian Government, Canberra, Australia. [online] URL: http://dfat.gov.au/about-us/publications/Pages/pacific-womenshaping-pacific-development-solomon-islands-country-plan-summary. $\underline{\operatorname{aspx}}$ 
Dyer, M. 2017b. Growing down like a banana: Solomon Islands village women changing gender norms. Asia Pacific Journal of Anthropology 18:193-210. http://dx.doi.org/10.1080/14442213.2017.1301544

Dyer, M. 2017a. Ungrounded cosmopolitanism: intersections of moral responsibility and gender in environmental activism in rural Solomon Islands. Women's Studies International Forum, in press. [online] URL: http://dx.doi.org/10.1016/j.wsif.2017.04.006

Evans, K., S. Flores, A. M. Larson, R. Marchena, P. Muller, and A. Pikitle. 2017. Challenges for women's participation in communal forests: experience from Nicaragua's indigenous territories. Women's Studies International Forum 65:37-46. http:// dx.doi.org/10.1016/j.wsif.2016.08.004

Filer, C., editor. 1997. The political economy of forest management in Papua New Guinea. The National Research Institute and the International Institute for Environment and Development, Boroko, Papua New Guinea.

Filer, C. 2000. How can Western conservationists talk to Melanesian landowners about indigenous knowledge? Resource Management in Asia Pacific Working Papers 27. Australian National University, Canberra, Australia. [online] URL: https:// openresearch-repository.anu.edu.au/handle/1885/40981

Foale, S. 2001. "Where's our development?": landowner aspirations and environmentalist agendas in Western Solomon Islands. Asia Pacific Journal of Anthropology 2:44-67. http://dx. doi.org/10.1080/14442210110001706105

Foale, S., and M. Macintyre. 2000. Dynamic and flexible aspects of land and marine tenure at West Nggela: implications for marine resource management. Oceania 71:30-45. http://dx.doi. org/10.1002/j.1834-4461.2000.tb02722.x

Frazer, I. 1997. The struggle for control of Solomon Island Forests. Contemporary Pacific 9:39-72.

Gal, S. 1991. Between speech and silence: the problematics of research on language and gender. Pages 175-203 in M. di Leonardo, editor. Gender at the crossroads of knowledge: feminist anthropology in the post modern era. University of California Press, Berkeley, California, USA.

Gay, D., editor. 2009. Solomon Islands diagnostic trade integration study. Solomon Islands Government Ministry of Foreign Affairs and External Trade, Honiara, Solomon Islands.

Hviding, E., and T. Bayliss-Smith. 2000. Islands of rainforest: agroforestry, logging and eco-tourism in Solomon Islands. Ashgate, Aldershot, UK.

Inter-Parliamentary Union (IPU). 2015. Women in national parliaments. IPU, Geneva, Switzerland. [online] URL: http:// www.ipu.org/wmn-e/classif.htm

Jolly, M. 2012. Introduction: engendering violence in Papua New Guinea: persons, power and perilous transformations. Pages 1-45 in M. Jolly, C. Stewart, and C. Brewer, editors. Engendering violence in Papua New Guinea. ANU E Press, Canberra, Australia. http://dx.doi.org/10.26530/OAPEN 459830

Kabeer, N. 2005. Gender equality and women's empowerment: a critical analysis of the third millennium development goal. Gender and Development 13:13-24. http://dx.doi.org/10.1080/13552070512331332273

Kabutaulaka, T. 2000. Rumble in the jungle: land, culture and (un)sustainable logging in Solomon Islands. Pages 88-97 in A. Hooper, editor. Culture and sustainable development in the Pacific. ANU E Press, Canberra, Australia.

Kabutaulaka, T. 2006. Global capital and local ownership in Solomon Islands' forestry industry. Pages 239-285 in S. Firth, editor. Globalisation and governance in the Pacific Islands. ANU Press, Canberra, Australia.

Kameswari, V. L. V. 2002. Gendered communication and access to social spaces: issues in forest management. Economic and Political Weekly 37:797-800.

Lederman, R. 1980. Who speaks here? Formality and the politics of gender in Mendi, highland Papua New Guinea. Journal of the Polynesian Society 89:479-498.

Macintyre, M. 2003. Petztorme women: responding to change in Lihir, Papua New Guinea. Oceania 74:120-134. http://dx.doi. org/10.1002/j.1834-4461.2003.tb02839.x

Macintyre, M. 2012. Gender violence in Melanesia and the problem of Millennium Development Goal No. 3. Pages 239-266 in M. Jolly, C. Stewart, and C. Brewer, editors. Engendering violence in Papua New Guinea. ANU E Press, Canberra, Australia.

Macintyre, M., and S. Foale. 2004. Global imperatives and local desires: competing economic and environmental interests in Melanesian communities. Pages 149-164 in V. Lockwood, editor. Globalisation and culture change in the Pacific Islands. Pearson Prentice Hall, Upper Saddle River, New Jersey, USA.

Maetala, R. 2008. Matrilineal land tenure systems in Solomon Islands: the cases of Guadalcanal, Makira and Isabel Provinces. Pages 35-72 in E. Huffer, editor. Land and women: the matrilineal factor. The cases of the Republic of the Marshall Islands, Solomon Islands and Vanuatu. Pacific Islands Forum Secretariat, Suva, Fiji.

McDougall, D. 2005. The unintended consequences of clarification: development, disputing, and the dynamics of community in Ranongga, Solomon Islands. Ethnohistory 52:81-109. http://dx.doi.org/10.1215/00141801-52-1-81

McDougall, D. 2014. "Tired for nothing"? Women, chiefs, and the domestication of customary authority in the Solomon Islands. Pages 199-226 in H. Choi, and M. Jolly, editors. Divine domesticities: Christian paradoxes in Asia and the Pacific. ANU Press, Canberra, Australia. http://dx.doi.org/10.22459/DD.10.2014.07

Meleisea, L., M. Measina, P. Schoeffel, S. Lauano, H. Boodoosingh, and M. Sahib. 2015. Political representation and women's empowerment in Samoa. Volume 1: Findings and recommendations. Centre for Samoan Studies National University of Samoa, Apia, Samoa.

Monson, R. 2011. Negotiating land tenure: women, men and the transformation of land tenure in the Solomon Islands. International Development Law Organization and Van Vollenhoven Institute, Leiden University, Rome, Italy. 
Monson, R. 2012. Hu nao save tok? Women, men and land: negotiating property and authority in Solomon Islands. Australian National University, Canberra, Australia.

Myers, F. R. 1986. Reflections on a meeting: structure, language, and the polity in a small-scale society. American Ethnologist 13:430-447. http://dx.doi.org/10.1525/ae.1986.13.3.02a00020

Myers, F., and D. Brenneis. 1984. Introduction: language and politics in the Pacific. Pages 1-30 in D. Brenneis, and F. Myers, editors. Dangerous words: language and politics in the Pacific. New York University Press, New York, New York, USA.

Oranje, D., and T. Duff. 2006. Solomon Islands forestry management project II (SIFMP II): National forest resource assessment update 2006. URS Sustainable Development, Canberra, Australia.

Porter, D., and M. Allen. 2015. The political economy of the transition from logging to mining in Solomon Islands. State, Society and Governance in Melanesia Discussion Paper Series. Australian National University, Canberra, Australia. [online] URL: https:// openresearch-repository.anu.edu.au/handle/1885/98441

Pryke, J. 2013. The Pacific's aid boom. Devpolicy Blog. Development Policy Centre, ANU College of Asia and the Pacific, Australian National University, Canberra, Australia. [online] URL: http://devpolicy.org/the-pacifics-aid-boom-02092013/

Quay, I. 2012. Pacific women's leadership scoping study. International Women's Development Agency, Melbourne, Australia. [online] URL: https://pacificwomen.org/research/ pacific-womens-scoping-study-final-report/

Sharp, T., J. Cox, C. Spark, S. Lusby, and M. Rooney. 2015. The formal, the informal, and the precarious: making a living in urban Papua New Guinea. State, Society and Governance in Melanesia Discussion Paper. The Australian National University, Canberra, Australia. [online] URL: http://bellschool.anu.edu.au/sites/ default/files/publications/attachments/2015-12/DP 20152 Sharp Cox Spark Lusby Rooney 0.pdf

Sprain, L., and D. Boromisza-Habashi. 2012. Meetings: a cultural perspective. Journal of Multicultural Discourses 7:179-189. http:// dx.doi.org/10.1080/17447143.2012.685743

Strachan, J., S. Akao, B. Kilavanwa, and D. Warsal. 2010. You have to be servant of all: Melanesian women's educational leadership experiences. School Leadership and Management: Formerly School Organisation 30:65-76. http://dx.doi. org/10.1080/13632430903509774

Tracy, K., and A. Dimock. 2004. Meetings: discursive sites for building and fragmenting community. Annals of the International Communication Association 28:127-165. http://dx.doi. org/10.1080/23808985.2004.11679034

UNICEF. 2011. Children in Solomon Islands: 2011. An atlas of social indicators. United Nations Children's Fund, Suva, Fiji. [online] URL: https://www.unicef.org/pacificislands/

Children_in_Solomon_Islands_2011_An_Atlas_of_Social_Indicators (1).pdf

United Nations. 2016. Goal 5: achieve gender equality and empower all women and girls. United Nations, New York, New York, USA. [online] URL: https://unstats.un.org/sdgs/files/metadata-compilation/ $\underline{\text { Metadata-Goal-5.pdf }}$
United Nations Development Programme (UNDP). 2015. Human development report 2015: work for human development. United Nations Development Programme, New York, New York, USA. [online] URL: http://hdr.undp.org/sites/default/ files/2015 human development report.pdf

UN Women. 2016. Solomon Islands: violence against women. UN Women: Asia Pacific, Suva, Fiji. [online] URL: http://asiapacific. unwomen.org/en/countries/fiji/co/solomon-islands

Wairiu, M. 2007. History of the forestry industry in Solomon Islands. Journal of Pacific History 42:233-246. http://dx.doi. org/10.1080/00223340701461684

White, G., and K. Watson-Gegeo. 1990. Disentangling discourse. Pages 3-52 in K. Watson-Gegeo and G. White, editors. Disentangling: conflict discourse in the Pacific. Stanford University Press, Palo Alto, California, USA.

World Bank. 2011. World development report 2012: gender equality and development. World Bank, Washington, D.C., USA. [online] URL: http://documents.worldbank.org/curated/en/492221468136792185/ Main-report

World Bank. 2015. World Bank East Asia and Pacific economic update October 2015: staying the course. World Bank, Washington, D.C., USA. [online] URL: http://pubdocs. worldbank.org/pubdocs/publicdoc/2015/10/414911444005973491/ pdf/EAP-Economic-Update-2015-10.pdf 